
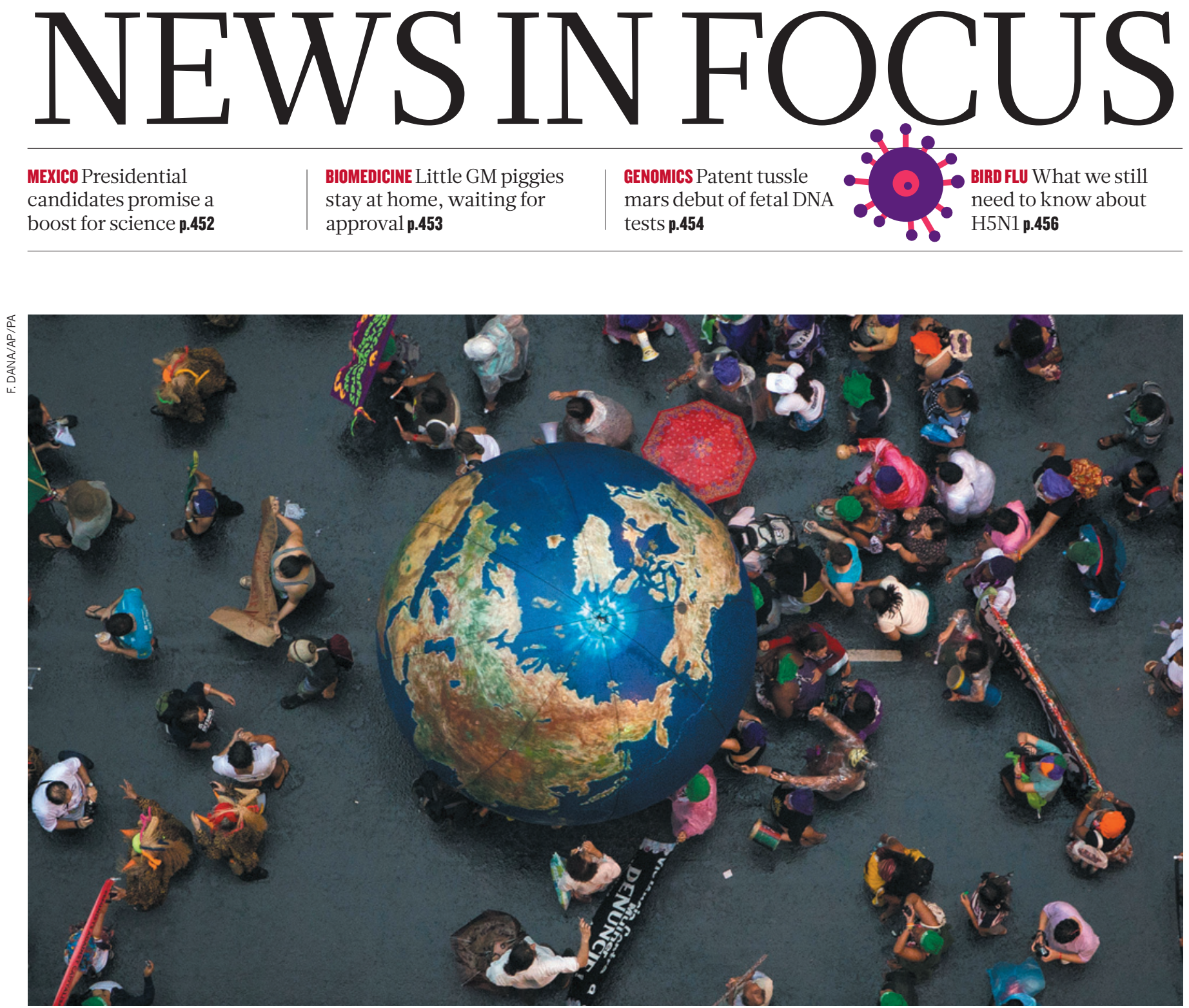

Environmental activists push an inflatable globe through the streets of Rio de Janeiro, Brazil, during multilateral talks on sustainable development.

\title{
Wealth gap curbs Rio goals
}

\section{Outcome of last week's Earth Summit reflects the divided priorities of rich and poor nations.}

\section{BY JEFF TOLLEFSON IN RIO DE JANEIRO}

$\mathrm{B}$ razil's celebrated coastal metropolis is defined by stark contrasts, both geographic and economic. Extravagant wealth rings the city's luxurious beaches, while poverty looks on from the haphazard developments called favelas that sprawl across the surrounding hills. Such conspicuous inequality is symbolic of the challenge humanity faces on a global scale - a problem that restricted progress at the Rio+20 meeting last week to a modest and mostly voluntary set of commitments.

"What has been agreed to is entirely insufficient to tackle the problems that are before us on environment and development," says Manish Bapna, acting president of the World Resources Institute, a global environment think tank in Washington DC.

The 49-page document adopted on 22 June at the close of Rio+20 - the United Nations Conference on Sustainable Development does many small things.

Called The Future We

Want, it establishes a process for crafting a set of sustainable-development goals that would

\section{$\rightarrow$ NATURE.COM}

For Nature's special on the Rio meeting, see:

go.nature.com/d69weu come into effect just as the UN Millennium Development Goals expire in 2015. It endorses efforts to reduce consumption, improve energy systems and encourage a greener world economy, and calls for an international governance system for conserving biodiversity in the high seas.

But the agreement offers little in the way of relief for an increasingly pressured biosphere. Whereas the first Earth Summit in Rio de Janeiro in 1992 served as a launch pad for landmark agreements such as the Convention on Biological Diversity and the UN Framework Convention on Climate Change, the 2012 
> meeting instead revolved around the thorny question of global inequality.

Poverty, not global warming or the environment, is "the greatest challenge that we face in the world today", said Luiz Alberto Figueiredo Machado, Brazil's chief negotiator, when a draft that ultimately became the final agreement was announced on 19 June. One of Brazil's slogans for the conference was "To grow, to include, to protect", and as talks commenced, developing countries aligned their priorities in that order.

Throughout the meeting, the developing countries that make up the Group of 77 negotiating bloc (G77) objected to language that they felt might constrain their ability to grow and lift citizens out of poverty. In one case, the G77, along with the United States, blocked a European proposal to acknowledge the existence of global environmental thresholds that should not be surpassed. Such 'planetary boundaries' could include levels of carbon dioxide in the atmosphere and acidification of the oceans. Developing countries also fought against commitments to pursue a green economy unless they were phrased in the context of economic and social development. For such nations, "inclusive growth and a rapid increase in per capita income levels are development imperatives", declared Indian Prime Minister Manmohan Singh in his conference address.

Yet industrialized countries, including the United States and those in the European Union, seemed to be too preoccupied with their own economic woes to step forward with major new financial commitments for poor countries. The final text of the agreement provided no concrete answers to long-standing questions about development aid.

Although talks among high-level officials made little headway, there was a flurry of activity at hundreds of side meetings. The UN counted more than 100 individual initiatives on renewable energy by governments, businesses and multilateral financial institutions such as the World Bank, and monetary commitments of more than US $\$ 513$ billion for a range of public and private initiatives on sustainable development. Many observers took such announcements as a sign that action is happening from the bottom up, even as international negotiations stall at the top. But others regarded the initiatives as too little, too late.

"There is compelling scientific evidence that we will lose invaluable species, ecosystems and their services under global warming as generated by business as usual with a few green speckles," says Hans Joachim Schellnhuber, director of the Potsdam Institute for Climate Impact Research in Germany. Schellnhuber says that governments are ignoring planetary boundaries at their own peril. "In this respect, the second Rio summit has utterly failed."

\section{HUMAN INVESTMENT}

Brazil as a country is emblematic of the economic imbalance that hung over the meeting and that threatens to hamper progress at future global environment talks. With the sixth largest economy in the world, Brazil is regarded abroad as an emerging power, but the country sinks to 101st in a ranking of gross domestic product per capita.

Rio de Janeiro's poorest districts, such as Cachoeirinha in the west, also offer a glimpse of the future for much of the planet. UN projections suggest that by 2025 , the world's cities could contain one billion new residents, most of whom will begin their lives in slums and poor

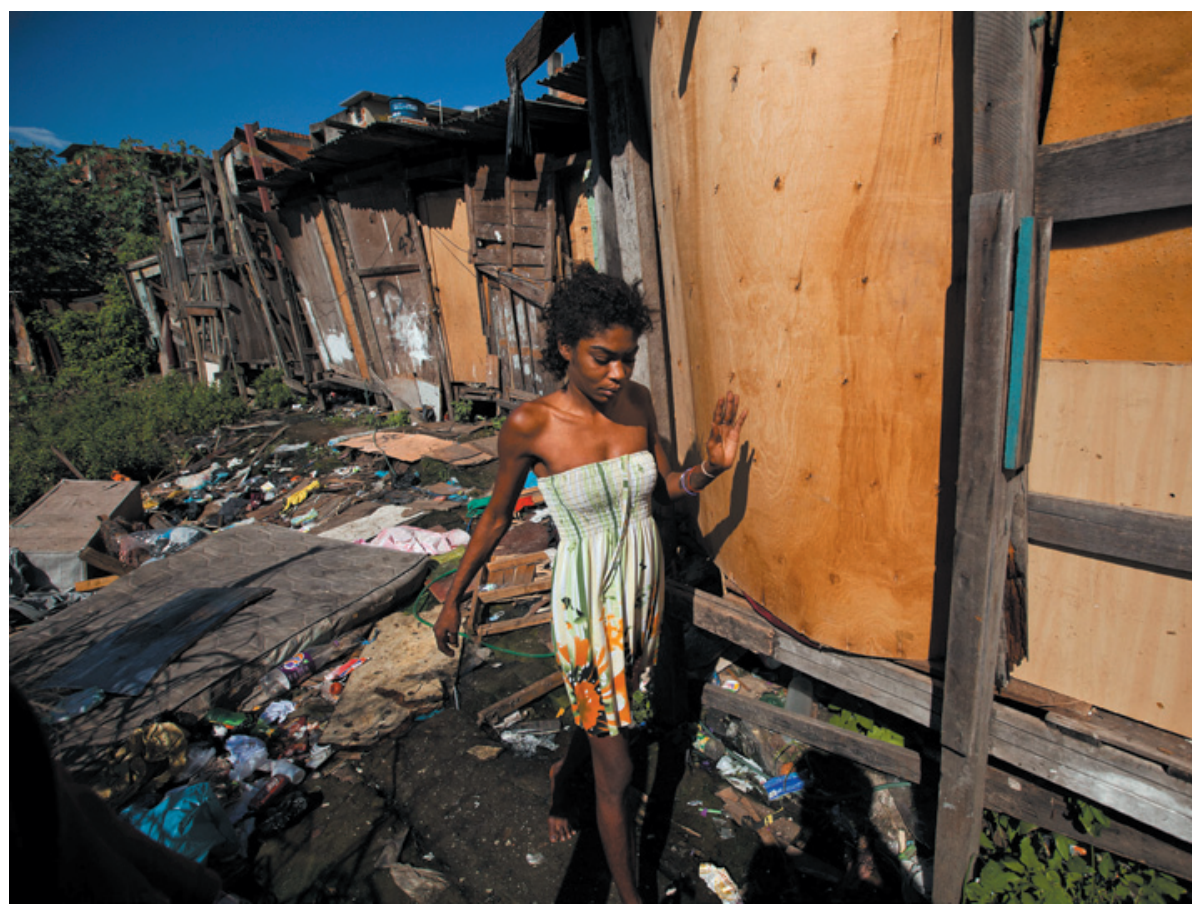

In the Manguinhos neighbourhood of Rio de Janeiro, talk of reducing consumption seems a world away. communities throughout the developing world. Jilson Roberto is head of the Cachoeirinha community association, and attended the 1992 Earth Summit to advocate for a greendevelopment plan on behalf of favelas. Roberto says that his community has little to show for the effort 20 years later. Cachoeirinha still lacks basic rubbish collection and floods regularly when it rains. The area also remains in the hands of drug traffickers, their territory marked by a pair of sofas blocking the road outside the community centre. Governments shouldn't forget about the current generation as they plan for the future, Roberto says. "We need to invest in human beings today."

To that end, the summit agreement calls for a high-level political forum to promote work on sustainable development. Its role and function remain to be worked out, but the Rio agreement suggests that the forum would conduct a regular scientific assessment of progress towards sustainable-development initiatives, says Gisbert Glaser, senior adviser at the International Council for Science in Paris, which represented scientists' interests in the Rio+20 negotiations.

More than ever, Glaser says, scientists need to work across disciplines to advise policymakers on a host of interrelated issues, from climate, energy and water to food, poverty and development. He adds that researchers need to develop metrics to help define sustainable development, similar to the carbon dioxide levels and temperature thresholds used to assess global warming, and then work with social scientists and economists to look for politically viable solutions. "This is a difficult thing to do," he says, "but we have to do it."

Examples of such complexity abound. When it comes to biofuels, for instance, governments must learn how to account for water use and international trade to understand the broader impacts of biofuel production on land use, biodiversity and food prices.

Biologist John Sulston of the University of Manchester, UK, who chaired a UK Royal Society working group that investigated links between global population and consumption, laments that the final agreement fails to link population to sustainable development. To Sulston, this is like planning a party without a guest list, "but on a unimaginably vast scale". In another example of the competing agendas at work behind such issues, the Vatican led a small group of countries in removing the term 'reproductive rights' from the text, despite pressure from family-planning groups.

Rather than complaining that global leaders have failed in the negotiations, Sulston says, scientists can and should work to help countries to develop new sustainable-development goals in the coming years. "Delving into the [agreement] text, we can see the skeleton of what we need to ensure our planet's future," he says. "From these bare bones we can raise an army." - 